\title{
Coconut Nut Rot Disease in India: Prevalence, Characterization of Pathogen and Standardization of Inoculation Techniques
}

\author{
R. Dheepa ${ }^{1 *}$, C. Goplakrishnan ${ }^{1}$, A. Kamalakannan ${ }^{1}$, S. Nakkeeran ${ }^{1}$, \\ C.A. Mahalingam ${ }^{2}$ and J. Suresh ${ }^{3}$ \\ ${ }^{1}$ Department of Plant Pathology, ${ }^{2}$ Department of Agricultural Entomology, Tamil Nadu \\ Agricultural University, Coimbatore -641 003, Tamil Nadu, India \\ ${ }^{3}$ Tamil Nadu Agricultural University, Coimbatore - 641 003, \\ Tamil Nadu, India \\ *Corresponding author
}

A B S T R A C T

\begin{tabular}{|l|}
\hline K e y w o r d s \\
Coconut nut rot; \\
Lasiodiplodia \\
theobromae, \\
Morphological and \\
molecular \\
characterization; \\
Scanning Electron \\
Microscope \\
\hline Article Info \\
\hline $\begin{array}{l}\text { Accepted: } \\
\text { 17 January } 2018 \\
\text { Available Online: } \\
\text { 10 February } 2018\end{array}$ \\
\hline
\end{tabular}

Keywords

Coconut nut rot;

Lasiodiplodia

molecular

Microscope

Accepted:

Available Online:

\section{Introduction}

Cocos nucifera $\mathrm{L}$. is a member of the family Arecaceae and one of the most important perennial tropical crops. India is the third largest producer of coconut, after Indonesia and Philippines (Asian and Pacific Coconut Community (APCC) Statistical Year Book 2014). The coconut palm is predominantly grown widely southern states of India including Tamil Nadu. India produced 20439.60 million nuts in an area of approximately 1975.81 million hectares with a productivity 10345 nuts per ha during 2015 (Horticulture Division, Dept. of Agriculture and Cooperation, Ministry of Agriculture, Govt. of India). Coconut production is limited by several factors, among them diseases play a major role. Nut rot is the major post-harvest disease of coconut in India, which causes 
significant yield losses up to 60 per cent (Viana et al., 2007). A fungus L. theobromae (Pat.) Griffon \& Maubl. is the only species that has been reported to be associated with this disease (Taylor and Hyde, 2003). L. theobromae is a cosmopolitan soil-borne fungus that causes both field and storage diseases in plant species leading to economic losses. Coconut nut rot was first observed to cause severe damage to coconuts in the southern state of Kerala in the late 1990's (Nair, 2000).

\section{L. theobromae (Botryosphaeriaceae:} Botryosphaeriales: Dothideomycetes: Ascomycota) is cosmopolitan in distribution; however, this species is more commonly found in tropical and subtropical regions (Punithalingam, 1980; Marques et al., 2013). This fungus is unique and destructive to crops because it can live endophytically in asymptomatic plant material and avoid detection by quarantine. Moreover, Lasiodiplodia species can ramify profusely when the host is under stress, causing significant yield losses (Slippers and Wingfield, 2007).

The accurate identification of pathogen is essential for devising proper control measures, quarantine programs, and to develop nut rot resistant coconut varieties. The present work was undertaken to assess the prevalence of nut rot in popular varieties of coconut in Tamil Nadu, Pathogens involved and its characterization, standardization of inoculation methods, mode of entry and susceptibility of different stages of nuts to $L$. theobromae infection.

\section{Materials and Methods}

\section{Survey and assessment of coconut nut rot}

A survey was conducted during 2015-2016 on the incidence of nut rot disease in different coconut growing areas of Tamil Nadu, viz. Coimbatore (Thondamuthur, Thadagam, Chinniyampalayam, Devarayapuram, Negamam and Aliyar), Tanjavur (Vepankulam and Peravoorani), Tiruppur (Chinnampalayam and Thali), Dharmapuri (Kaveripattinam, Arasampatti and Bommidi), Kanyakumari (Marthandam), Erode (Thalavadi, Pandiyampalayam and Chennampatti), Vellore (Tirupattur), Salem (Edappaadi, Morepalayam, Karuppur and Tharamangalam), Ariyalur (Suthamalli) and Trichy (Kattuputtur). In each village, four fields were selected and four plots in each field having average nuts of 100 numbers were marked at random. Lesions on the surface of the nut was measured, using 0-3 scale; (where $0=$ no lesion; $1=25$ per cent area affected; $2=26-50$ per cent area affected and $3=>50$ per cent area affected) as per scale proposed by Lakshmanan and Jagadeesan, (2004).

\section{Isolation and purification of fungal pathogen}

Seven-month-old nuts (cv. Local) showing malformation and cracking symptoms were obtained from Coconut farm, Tamil Nadu Agricultural University, Coimbatore, Tamil Nadu. Diseased tissues from the edge of the lesion were collected and surface-disinfected with 0.5 per cent $\mathrm{NaOCl}$ for 3 min., then placed on potato-dextrose-agar (PDA) in $9 \mathrm{~cm}$ Petri plates, and incubated at $25 \pm 3^{\circ} \mathrm{C}$ for 7 days (Phipps and Porter, 1998). Stock cultures of $L$. theobromae were obtained using the hyphal tip transfer procedure (Rangaswami et $a l .$, 1975) and maintained in tube slants of PDA at $10^{\circ} \mathrm{C}$.

\section{Morphological characterization of $\boldsymbol{L}$. theobromae}

Fifteen isolates of $L$. theobromae were sub cultured on PDA medium on Petri dishes (90 
$\mathrm{mm}$ in diameter) for correlation of phenotypic and growth characters. Eight-millimetre disc from margins of actively growing seven-dayold fungal culture were inoculated on the centre of Petri dishes containing PDA medium. Colony colour and texture observations were recorded after seven days of incubation. Species differentiation was possibly made between them by studying the colony character, pcynidia and conidia morphology (Waller and Lenne, 2002). For further confirmation the culture has been sent to Indian Agricultural Research Institute.

\section{Microscopic observations of $L$. theobromae}

The conidia were scraped from infected nuts and mounted in a lactophenol solution on a microscopic slide. Measurements of the conidia were made using a light microscope (Labomed-IVU 5100) and photographed using a Labomed camera model LX400 with an image analyser - pixelpro programme.

\section{Pathogenicity test}

In order to prove Koch's postulates, pathogenicity test was carried out. Seven month old coconuts (cv. Local) were collected from the university coconut farm, washed thoroughly under running tap water. The coconuts were blot dried and surface sterilized with 70 per cent ethanol. Five month old coconuts were injured with sterilized needle and $9 \mathrm{~mm}$ mycelial disk from virulent isolate of $L$. theobromae (LDt3TM1) was placed on coconuts. A thin layer of sterilized moist cotton was placed over the inoculated coconuts. Inoculated coconuts were kept in a humid chamber using plastic bags for fifteen days under laboratory conditions. Untreated controls were inoculated with plain PDA discs only. The fungus was reisolated from the artificially inoculated coconuts showing typical nut rot symptoms and the culture obtained was confirmed for its morphology and colony characters.

\section{Methods of inoculation}

The virulent isolate of $L$. theobromae (LDt3TM1) was used for artificial inoculation of the seven month old coconuts using (cv. Local) collected from the university coconut farm. The spore suspension $\left(5 \times 10^{5}\right.$ spores $/ \mathrm{ml}$ ) of the pathogen was prepared using a seven day old PDA culture by grinding it with sterile distilled water in a pestle and mortar. The coconuts were washed with running tap water; surface sterilized with 70 per cent alcohol and washed with sterile distilled water. The following methods were used for inoculation of the coconuts.

i. Coconuts inoculated with spore suspension after pin prick using sterile entomological pins.

ii. Coconuts inoculated with spore suspension without pin prick.

iii. Coconuts inoculated with mycelium after pin prick.

Coconuts inoculated with sterile distilled water after pin prick served as control. The inoculated coconuts surfaces were covered with moist cotton and coconuts were kept inside the moist chamber. Five coconuts were used for each method. Four replications were maintained. The infection was recorded after seven days and the Per cent Disease index was calculated.

\section{Results and Discussion}

\section{Survey for the assessment of nut rot in coconut}

A survey was conducted in various districts of Tamil Nadu to assess the occurrence of $L$. theobromae infected coconuts. Malformed and cracked nuts in all stages were collected. Further observation revealed the presence of L.theobromae@50-100 conidia/microscopic field. The survey also revealed that the incidence of $L$. theobromae varied from 5.1 to 22.0 per cent (PDI) in different districts of Tamil Nadu. The lowest incidence of the 
disease (PDI - 5.1, 6.19, 6.69, 6. 83, 7. 29, 8.48 and 9. 56) was recorded in Thadagam (CBE), Panjapatti (Karur), Tirupattur (Vellore), Devarayapuram (Coimbatore), Chennampatti (Erode), Thalavadi (Erode), Suthamalli (Ariyalur) and Morepalayam (Salem) respectively. Maximum occurrence of the disease was recorded in Thondamuthur (Coimbatore), Peravoorani (Tanjavur), Pandiyampalayam (Erode) and Chinnampalayam (Thiruppur) (PDI - 22.00, 21.30, 19.40 and 18.40), followed by Vepankulam (Tanjavur) and Tharamangalam (Salem) (PDI- 18.00 and 17.50) respectively (Table 1). The disease was prevalent in all major Agro Climatic Zones of Tamil Nadu. The young palms of 5-10 years were found to be more susceptible to nut rot than matured palms. The pathogen responsible for this disease was isolated from the infected samples collected during survey and it was confirmed as $L$. theobromae, which causes brown lesions covering entire nut surface, later turning into whitish grey colour having shrivelled appearance (Fig. 1a; 1b). Similarly, the world wide post-harvest losses have been estimated as 50 per cent and much of this is due to microbial decay (EI- Ghaouth and Wilson, 1995). Post-harvest losses occur at various stages, viz., storage loss, transportation loss and loss at the level of wholesaler or retailer or consumer (Dasgupta and Mandal, 1989).

\section{Morphology and Identification of the pathogen}

The mycelium of the isolated fungus grew uniformly in all directions and fully covered the surface of the media within 3 to 4 days. The colour of the colony changed gradually from light grey at four to seven days of incubation to black after two weeks of incubation. The bottom most part of the fungus only became darker after 3 weeks of incubation. Subsequently, the fungus produced stromata and pycnidia. The pycnidia produced were initially soft but hardened when the culture matured at 4 weeks. The culture has sporulated only after 4 weeks of incubation. Fruiting bodies developed after 4 weeks of incubation (Fig. 2a). Liquid exudates were produced and became dry after five days. After they dried, the spores were released from the ostioles in the form of a black dust on the culture media (Fig. 2b). The main characteristics of $L$. theobromae are presence of paraphyses within the pycnidia, and conidia that are initially hyaline and aseptate but become brown and one septate with age, forming longitudinal striations due to the deposition of melanin granules on the inner surface of the wall. Type culture of pathogen was submitted to Indian Type Culture Collection (ITCC), Division of Plant Pathology, Indian Agricultural Research Institute, New Delhi with the accession number of $10,517.17$. The results are more or less similar to those obtained from a morphological and cultural basis reported by Burgess et al., (2003). In view of its widespread occurrence, wide host range and its known morphological variability (Punithalingam, 1980), it is possible that $L$. theobromae is composed of a number of cryptic species.

\section{Morphological variability among $L$. theobromae isolates}

Among the fifteen isolates studied for their morphological characters, six isolates, namely PKLDt1, CMPLDt2, LDt3TM1, POLLDt4, KVPMLDt9 and TPRLDt13, showed a colony growth rate of 24.50 to $25.60 \mathrm{~mm}$ /day indicating their fast growing nature. These isolates filled the entire $90-\mathrm{mm}$ diameter Petri dish surface in $96 \mathrm{~h}$. Six isolates viz., LDt6VPN, KGMLDt7, UDULDt8, TVDLDt12, SMLDt15 and KSGLDt10 exhibited a moderate growth rate that ranged between $23.40 \mathrm{~mm}$ and $24.30 \mathrm{~mm}$. The lowest 
growth rate was observed in the isolates of ALILDt5, NGLLDt11 and EDPLDt14. The majority of the isolates showed vegetative growth, four isolates showed fluffy colony growth and three isolates were oppressed to the culture medium. Almost all the isolates showed a uniform growth pattern, except LDt6VPN, which exhibited an irregular growth pattern.

The colony colour of isolates was dull white (ALILDt5 and SMLDt15), cottony white changing to black (LDt6VPN and KGMLDt7), cottony greyish black (PKLDt1, CMPLDt2, LDt3TM1, UDULDt8, KVPMLDt9, TVDLDt12 and TPRLDt13), greyish white (POLLDt4 and KSGLDt10) and whitish (EDPLDt14, SMLDt15) (Table 2). Despite the fact that morphological and pathological variability existed among the isolates concerned, the slightest comparable relationship existed between morphologically similar isolates and their pathological behaviour (Mali et al., 2005). Similarly, Slippers et al., (2014) reported that, most frequently described morphological characteristics include conidial and paraphyses morphology and, to a lesser extent, cultural characteristics of growth and pigment production.

\section{Microscopic observations of $L$. theobromae}

Observation of pycnidia on the infected coconut mesocarp was often found to be dark brown to black. Immature conidia were sub ovoid to ellipsoid, apex rounded; truncate at the base, thick walled, hyaline and single celled, matured conidia dark brown, two celled with irregular longitudinal striations measuring 20.2-25.3 x 10.3-3.9 mm observed under 40X magnification (Fig. $3 \mathrm{a}$ and $3 \mathrm{~b}$ ). Similarly, Lasiodiplodia theobromae is pleomorphic and member of the sphaeropsidales with immersed to erumpent or superficial, pilose or glabrous, simple or often aggregated pycnidia reaching upto 5 $\mathrm{mm}$ width, with or without stroma. The pycnidia are usually papillate with prominent ostiole. Conidia are initially hyaline, unicellular, ellipsoid to oblong, thick walled with granular contents. On maturity the conidia became 2-celled, dark brown, usually 20-30 X 10-15 mm, with differentially pigmented longitudinal bands resembling striation (Punithalingam, 1980).

\section{Pathogenicity test}

In order to prove the Koch's postulates, the pathogenicity of $L$. theobromae isolate (LD3TM1) on coconut (cv. Local) was carried out. Pathogenicity test was conducted in vitro on fully matured and immature coconuts by following 'pin prick plus mycelial disc method'. The results revealed the development of symptom on all coconuts inoculated with the mycelial disc of $L$. theobromae within ten days, initially the inoculated nuts showed typical triangular yellow patches radiating from the perianth. Later yellow patches turned into brown lesions which covered more than 50 per cent of the nut surface (Fig. 4a).

Numerous black pycnidia were formed on the diseased lesions. Later, brown lesions turned into whitish grey, shrivelled and developed hardiness (Fig. 4b). All the isolates were pathogenic to coconut. In the field also similar types of symptoms were recorded within 15 days on nuts inoculated with the fungus after pin pricks, underneath of the perianth.

Typical cracking symptoms were recorded when disease intensity reached grade 3 . In 37 per cent of the diseased nuts, the fungus entered into the kernel through mesocarp, resulting in decay of the endosperm (Fig. 4c). 
Table.1 Survey on the incidence of coconut nut rot disease in coconut plantations of Tamil Nadu

\begin{tabular}{|c|c|c|c|c|c|c|}
\hline Sl. No. & Place of collection & District & Variety & $\begin{array}{c}\text { Age } \\
\text { (Years) }\end{array}$ & $\begin{array}{l}\text { Sole crop } \\
\text { / Inter crop }\end{array}$ & $\begin{array}{l}\text { Nut Rot } \\
\text { Incidence } \\
\text { (PDI) }\end{array}$ \\
\hline 1 & Thadagam & Coimbatore & Pollachi tall & 44 & Sole & 5.1 \\
\hline 2 & Chinniyampalayam & Coimbatore & Chawghat Orange & 35 & Sole & 18.4 \\
\hline 3 & Devarayapuram & Coimbatore & Pollachi tall & 13 & Sole & 6.7 \\
\hline 4 & Negamam & Coimbatore & Pollachi tall & 28 & Sole & 12.5 \\
\hline 5 & Aaliyar & Coimbatore & Pollachi tall & 20 & Cocoa & 11.4 \\
\hline 6 & Vepankulam & Tanjavur & Chawghat Orange & 14 & Sole & 18.0 \\
\hline 7 & Chinnampalayam & Tiruppur & Chawghat Orange & 08 & Fodder & 18.4 \\
\hline 8 & Thali & Tiruppur & West Coast tall & 30 & Sole & 12.1 \\
\hline 9 & Kaveripattinam & Dharmapuri & Local variety & 45 & Sole & 13.5 \\
\hline 10 & Kasargode & Kerala & Chawghat Orange & 12 & Sole & 16.7 \\
\hline 11 & Marthandam & Kanyakumari & $\begin{array}{l}\text { Local variety } \\
\text { Orange }\end{array}$ & 32 & Sole & 10.0 \\
\hline 12 & Thalavadi & Erode & W.C. tall & 27 & Pulses & 7.3 \\
\hline 13 & Tirupattur & Vellore & Arasampatti tall & 12 & Sole & 6.2 \\
\hline 14 & Edapaadi & Salem & Arasampatti tall & 16 & Sole & 12.0 \\
\hline 15 & Suthamalli & Ariyalur & Arasampatti tall & 30 & Sole & 8.5 \\
\hline 16 & Pandiyampalayam & Erode & Hybrid (DxT) & 07 & Turmeric & 19.4 \\
\hline 17 & Thondamuthur & Erode & Hybrid (DxT) & 23 & Turmeric & 22.0 \\
\hline 18 & Morepalayam & Salem & Hybrid (DxT) & 13 & Sole & 9.6 \\
\hline 19 & Karuppur & Salem & Hybrid (DxT) & 18 & Sole & 17.0 \\
\hline 20 & Arasampatti & Dharmapuri & Hybrid (DxT) & 40 & Sole & 11.8 \\
\hline 21 & Tharamangalam & Salem & Hybrid (DxT) & 32 & Sole & 17.5 \\
\hline 22 & Panjapatti & Karur & Local & 60 & Sole & 6.2 \\
\hline 23 & Kattuputtur & Trichy & Hybrid (DxT) & 12 & Sole & 14.0 \\
\hline 24 & Peravoorani & Tanjavur & Hybrid (DxT) & 10 & Sole & 21.3 \\
\hline 25 & Bommidi & Dharmapuri & Hybrid (DxT) & 23 & Sole & 15.7 \\
\hline 26 & Chennampatti & Erode & Hybrid (DxT) & 35 & Sole & 7.0 \\
\hline \multicolumn{6}{|c|}{ Mean } & 13.00 \\
\hline
\end{tabular}


Table.2 Colony characters of $L$. theobromae isolates collected from different coconut growing regions of Tamil Nadu

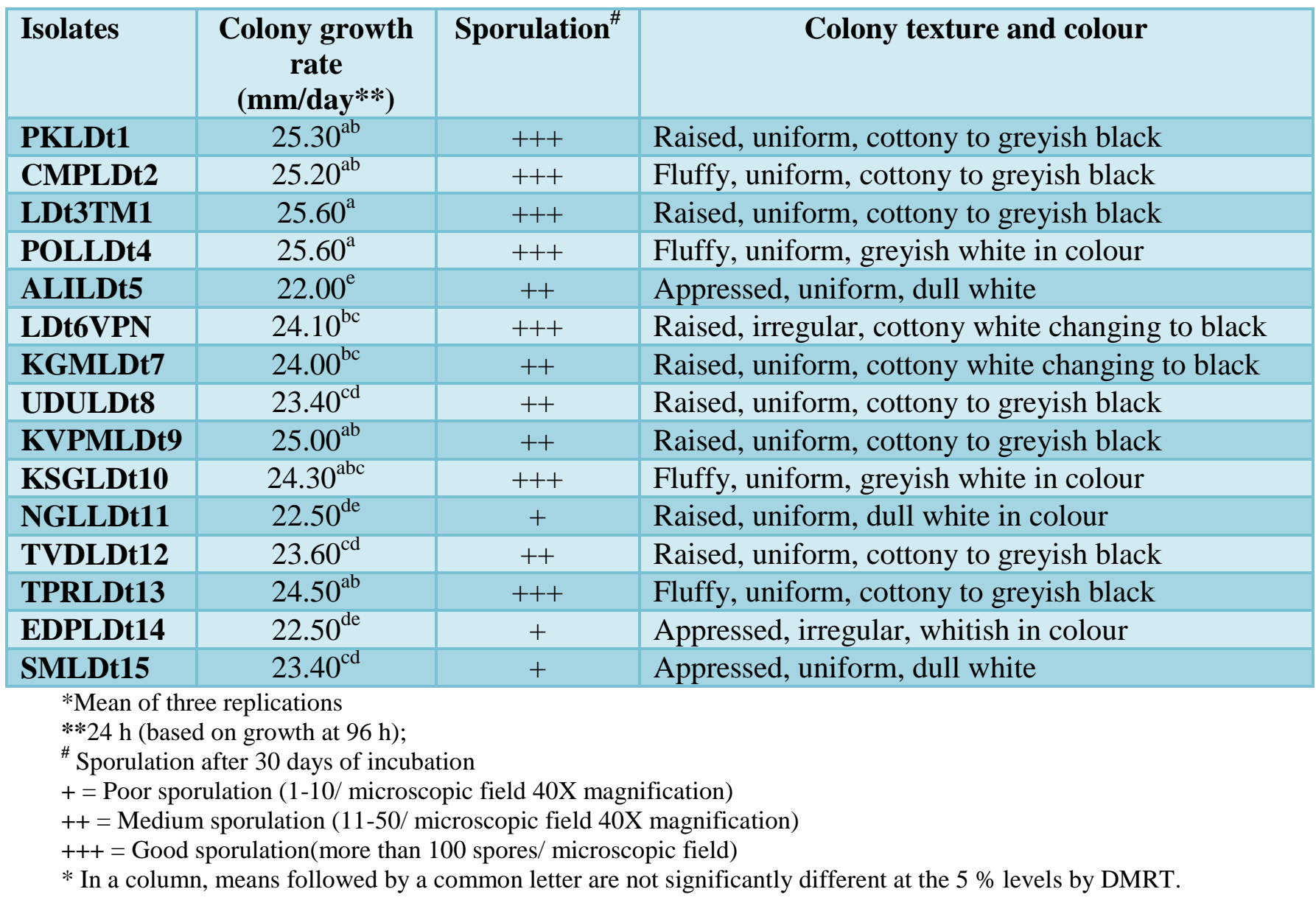

Table.3 Effect of different methods of inoculation on severity of coconut nut rot (cv. Local)under lab condition

\begin{tabular}{|c|l|l|}
\hline Sl. No & \multicolumn{1}{|c|}{ Technique } & \multicolumn{1}{c|}{ PDI $*$} \\
\hline $\mathbf{1}$ & Pin prick + Spore suspension & $\mathbf{6 8 . 5 0}^{\mathbf{a}} \mathbf{( 5 5 . 8 6 )}$ \\
\hline $\mathbf{2}$ & Spore suspension spray alone & $\mathbf{4 1 . 8 0}^{\mathbf{b}} \mathbf{( 4 0 . 2 7 )}$ \\
\hline $\mathbf{3}$ & Pin prick + Mycelial inoculation & $\mathbf{2 7 . 3 5}^{\mathbf{c}} \mathbf{( 3 5 . 2 4 )}$ \\
\hline $\mathbf{4}$ & Mycelial inoculation alone & $\mathbf{3 1 . 5 3}^{\mathbf{d}} \mathbf{( 2 4 . 5 2 )}$ \\
\hline $\mathbf{5}$ & Control & $\mathbf{0 . 0 0}^{\mathbf{e}} \mathbf{( 1 . 2 8 )}$ \\
\hline
\end{tabular}

*Mean of four replications.

In a column, means followed by a common letter is not significantly different at the $5 \%$ level by DMRT.

Values in parentheses are arcsine transformed values. 


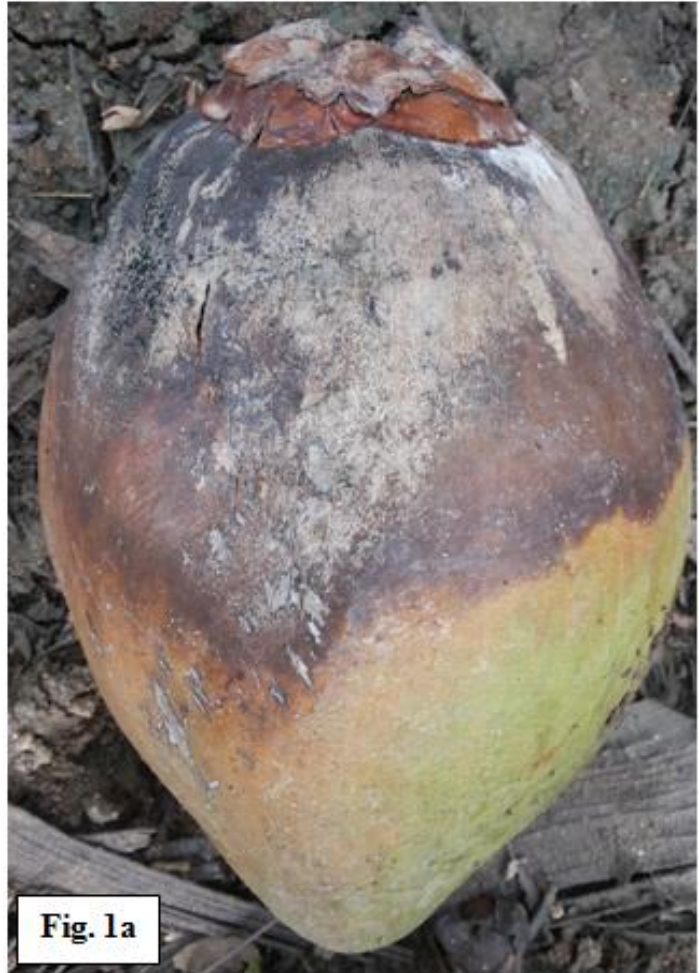

Fig. la. Brown lesions along with pycnidia covering entire nut surface

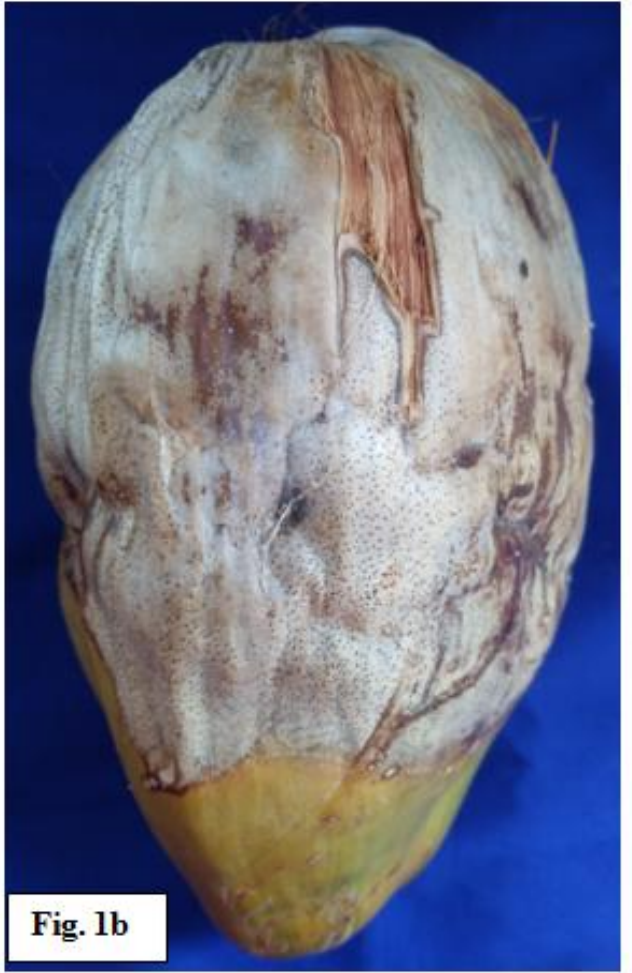

Fig. 1b. later tuming into whitish grey colour having shrivelled appearance

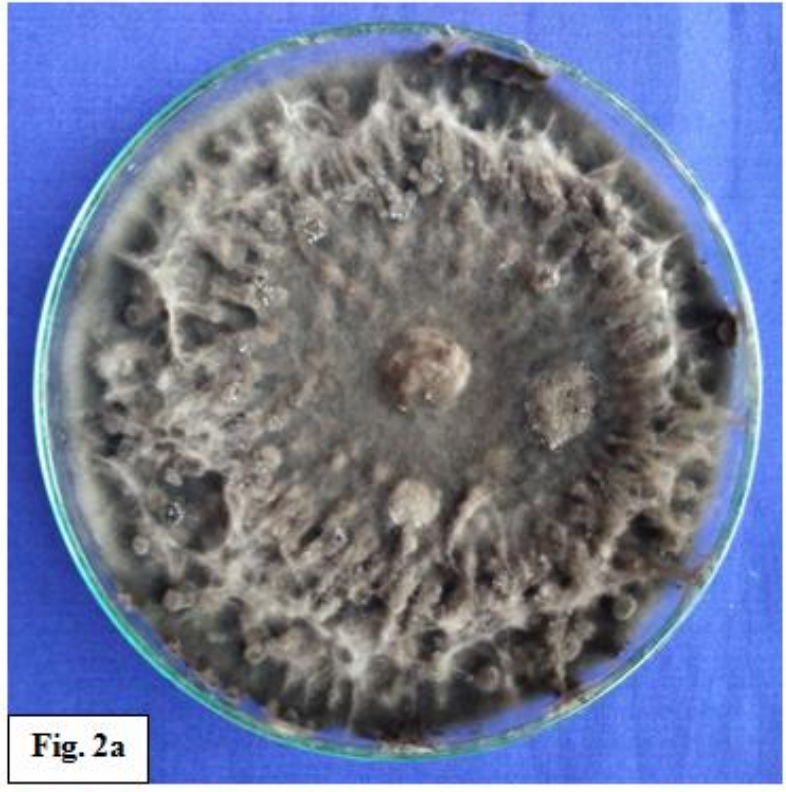

Fig.2a. Pure culture of $L$. theobromae produced fruiting bodies developed after 4 weeks of incubation

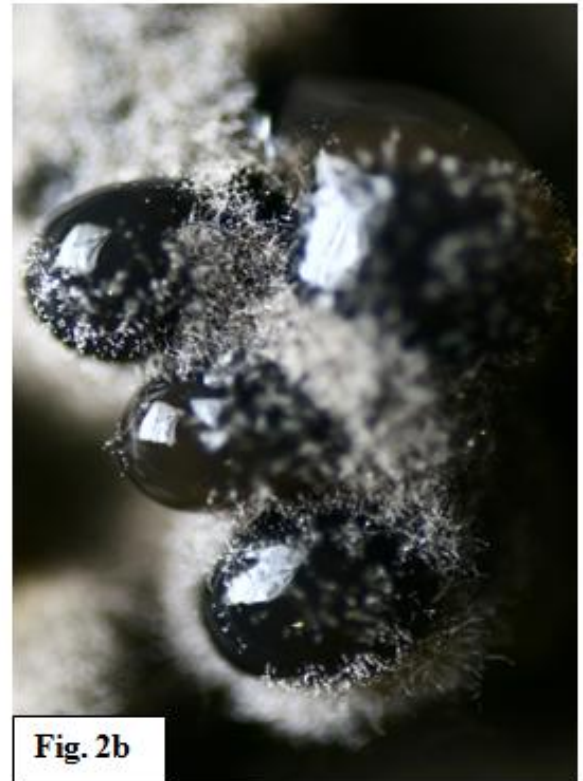

Fig.2b. Liquid exudates produced developing fruiting bodies 

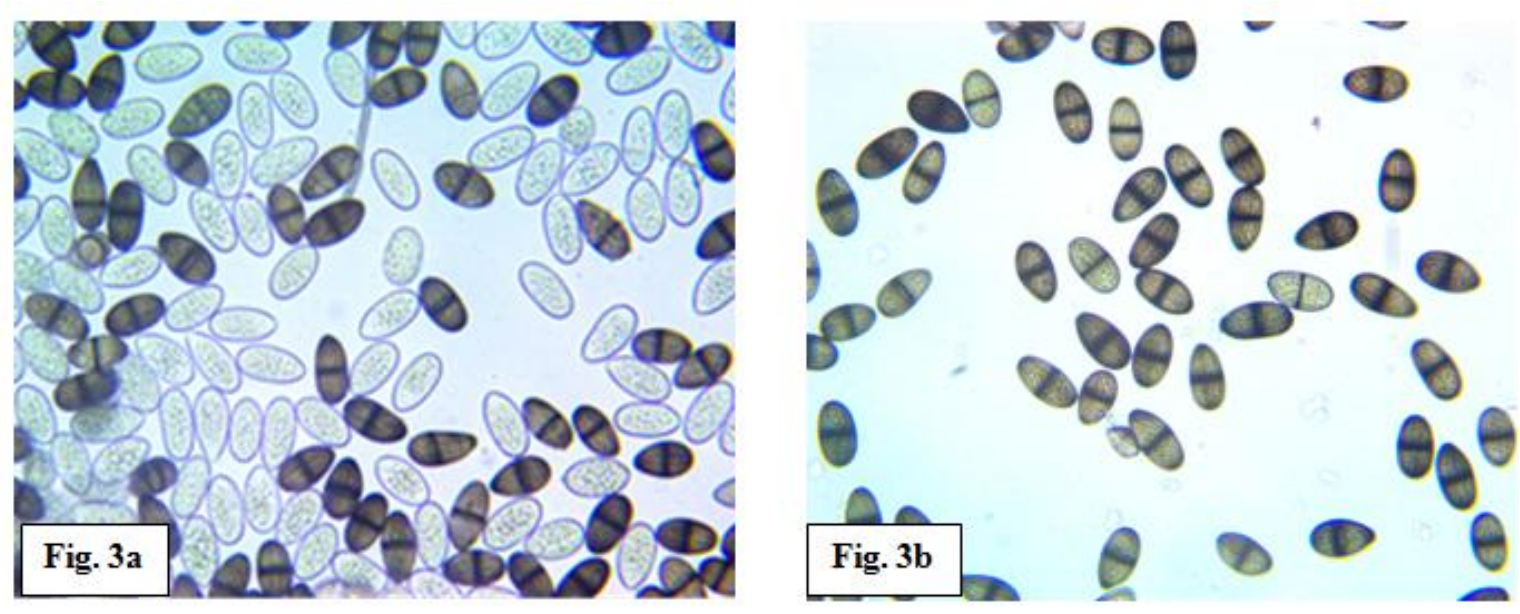

Fig. 3a. Immature condia single celled and hyaline; Fig. 3b. Mature conidia were observed to be septate, oval shaped and brown in colour with the presence of irregular longitudinal striations@ @ 40X magnification

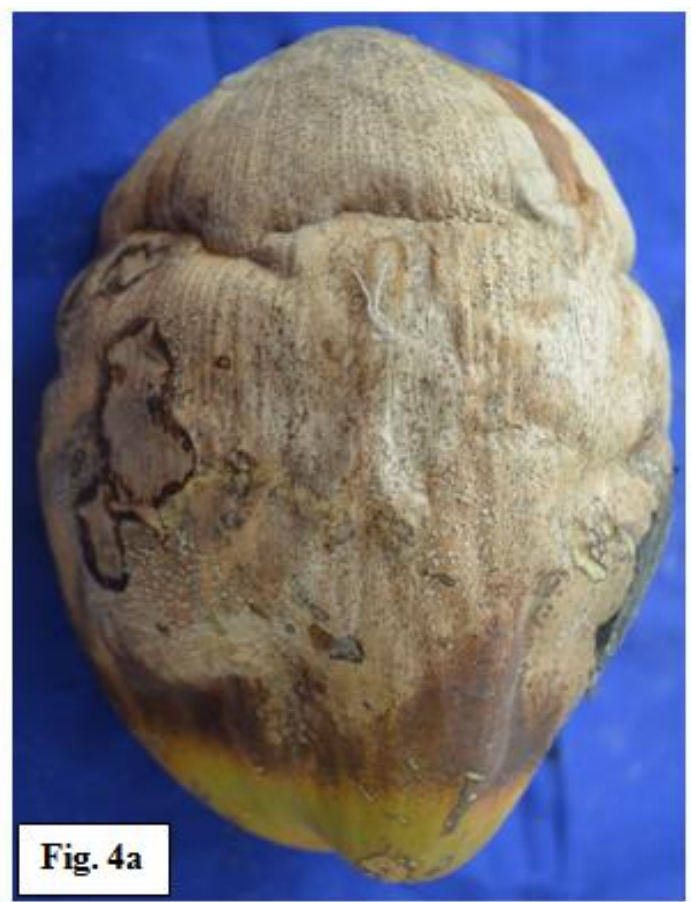

Fig. 4a. Yellow patches tumed into brown lesions which covered more than 50 per cent of the nut surface

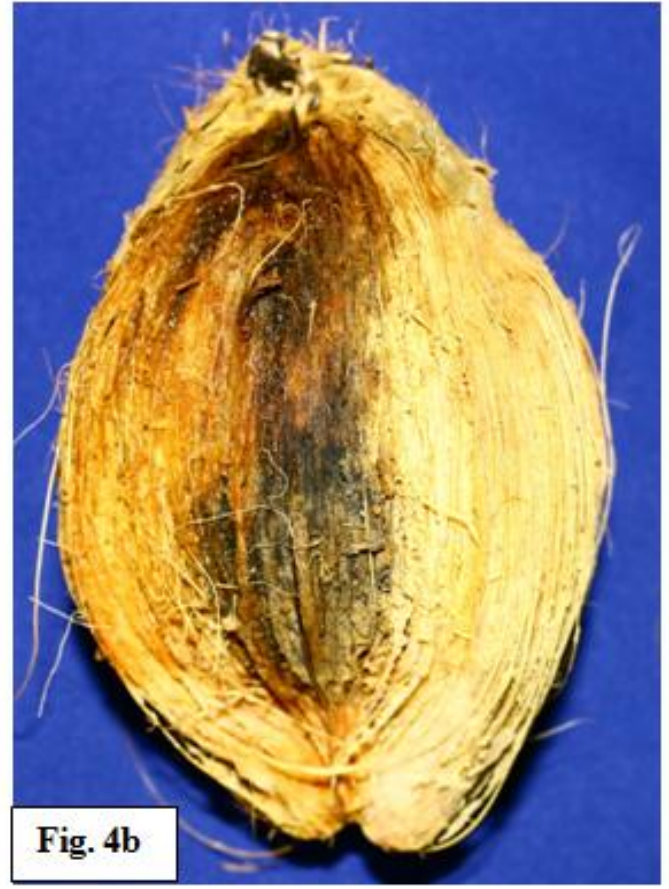

Fig. 4b. Dehusked coconut with rotting tissues 


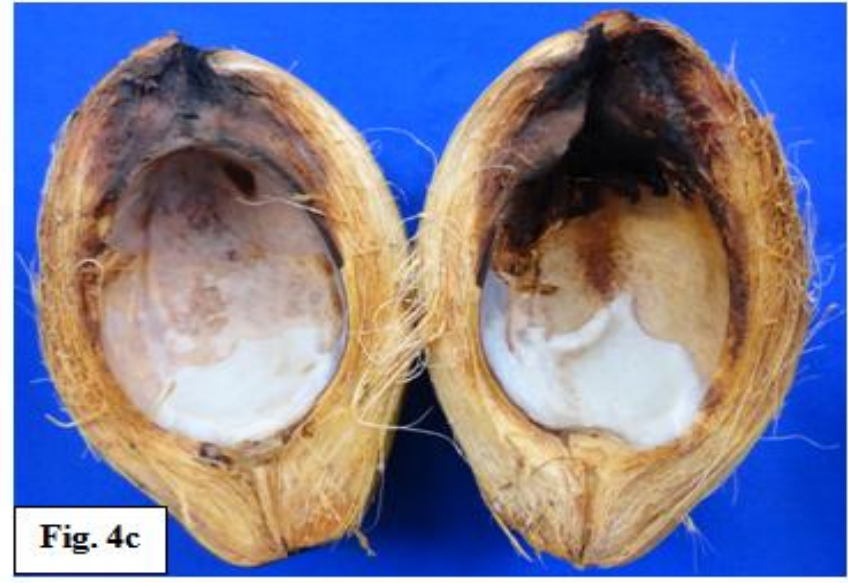

Fig.4c. Longitudinal splitting of nuts showing the fungus progressing into the endosperm

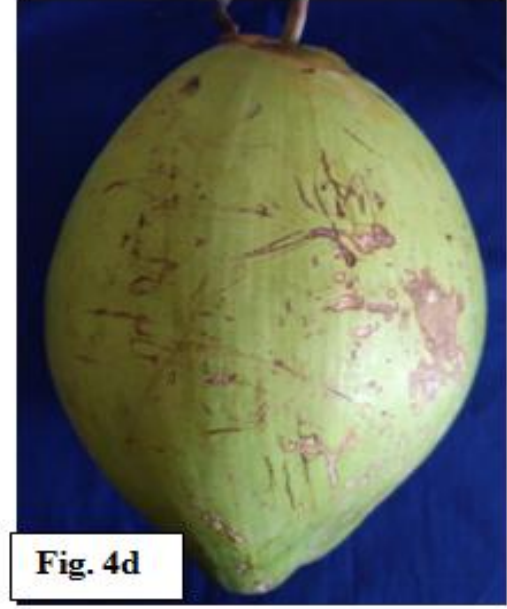

Fig. 4d. Control
In advanced stages, all nuts were malformed and developed hardiness, and such nuts dropped prematurely. The coconuts maintained as control did not show any symptoms (Fig. 4d). Koch's postulates were fulfilled by consistently re-isolating $L$. theobromae from inoculated coconuts. Inoculations were repeated twice and obtained the same results. Similar results were found by Rosado et al., (2016). In addition to devaluation of the crop due to esthetic damage, $L$. theobromae can also progress into the endosperm, rendering the coconut water unfit for consumption and resulting in significant monetary losses. Thus, $L$. theobromae was the most common and most aggressive species that is associated with the postharvest nut rot of coconut. Viana et al., (2007) reported that the main symptoms are the blacking and cracking of basal parts of the fruits. Water oozing may occur as the infection progresses. The fungus Lasiodiplodia theobromae has been frequently isolated from the lesions.

\section{Methods of inoculation}

Effect of different methods of inoculation of L. theobromae isolate (LDt3TM1) on seven month old coconut (cv. Local) was studied in vitro. The different methods of artificial inoculation viz., mycelial inoculation with pin prick, spore suspension spray with pin prick, spore suspension spray without pin prick, were tried on coconuts. The results indicated that the intensity of disease symptoms varied significantly with different methods of inoculation. Among the different methods of inoculation, pin prick with spore suspension spray was found to be the best which record a severity of 68.50 PDI followed by spore suspension spray without pin prick (41.80 PDI). A lowest PDI of 27.35 was recorded in mycelial inoculation with pin prick method (Table 3). The results of Rivera et al., (2006) revealed that wounding or puncturing of agave and Chinese rose leaves before application of spores resulted in the highest per cent infection of Colletotrichum gloeosporioides when compared to spore suspension spray alone. Manjunath (2009) reported the same in noni plants with $C$. gloeosporioides. Similar findings were also reported in Colletotrichum capsici (Anand, 2002). These findings suggested that wounding or injuries are the major factors for the disease initiation and further development.

This work represents the detailed report of $L$. theobromae as a causal agent of post-harvest 
disease coconut nut rot. The results of this study may be helpful for further studies on management measures, quarantine programs, or the development of coconut nut rot resistance coconut varieties.

\section{Acknowledgements}

The publication is a part of Ph.D. (Ag) thesis. I would like to thank the Department of Plant Pathology, Centre for Plant Protection Studies and Dean (School of Post Graduate Studies), Tamil Nadu Agricultural University and University Grants Commission - New Delhi for their financial support.

\section{References}

Anand, T. 2002. Studies on fruit rot of chilli (Capsicum annuum L.) caused by Colletotrichum capsici (Syd.) Butler and Bisby, and Alternaria alternata $(\mathrm{Fr})$ Keissler. M.Sc. (Ag.) Thesis, Tamil Nadu Agricultural University, Coimbatore, India, pp: 157.

Burgess, T., Wingfield, M.J. and Wingfield, B.D. 2003. Development and characterization of microsatellite loci for the tropical tree pathogen Botryosphaeria rhodina. Mol. Ecol. Notes., 3: 91-94.

Dasgupta, M. K. and Mandal, N. C. 1989. In; Postharvest Pathology of Perishables, New Delhi, Oxford and IBH Publishing Co., Pvt. Ltd. pp.1-623.

EI - Ghaouth, A. and Wilson, C. L. 1995. Biologically-based technologies for the control of postharvest diseases. Postharvest Biol. Technol., 6: 5-11.

Lakshmanan, P. and Jagadeesan, R. 2004. Malformation and cracking of nuts in coconut palms (Cocos nucifera L.) due to the interaction of the eriophyid mite, Aceria guerreronis and Botryodiplodia in Tamil Nadu, India. J. Plant Dis. Protect., 111: 206-207.
Mali, B.L., Rakesh, A. S. and Bhatnagar. M. K. 2005. A new host record of Lasiodiplodia. J Mycol Plant Pathol., 35: 70-72.

Manjunath, H. 2009. Morphological and molecular characterization of Alternaria alternata and Colletotrichum gloeosporioides incitants of leaf blight and anthracnose diseaseas of Noni and their Management, M.Sc.(Ag) Thesis, Tamil Nadu Agricultural University, Coimbatore, India, p. 222.

Marques, M. W., Lima, N.B., Morais, M.A., Barbosa Souza, M. A. G., Michereff, S. J. and Phillips Câmara. M. P. S. 2013. Species

of Lasiodiplodia associated with mango in Brazil. Fungal Divers., 61: 181-193.

Misra, A.P. and Mohammad. A.1964. Botryodiplodia rot of coconut (Cocos nucifera L.) in Bihar. Pro. Bihar Academy of Agricul. Sci., 12-13: 53-54.

Nair, G.M., Mathew, T.B., Saradamma, K. and Beevi, N. 2000. Infestation of coconut mite (Aceria guerreronis K.) in southern Indian state, Kerala. In: Proceedings international workshop on coconut eriophyid mite, CRI, Sri Lanka, pp. $32-40$.

Phipps, P.M. and Porter, D.M. 1998. Collar rot of peanut caused by Lasiodiplodia theobromae. Plant Dis., 82: 1205-1209.

Punithalingam, E.1980. Plant diseases attributed to Botryodiplodia theobromae Pat. In: Bibliotheca Mycologica Series, No. 71, J. Cramer, Vaduz, Liechtenstein. Marques Rangaswami, G., Kandasamy, T.K. and Ramasamy, K. 1975. Pleurotus sajor саји (Fr.). Singer-protein rich nitrogen fixing mushroom fungi. Current sci., 44: 403 - 444.

Rivera, Y., Rivera, L.I., Beaver, J.S., Erpelding, J.E., Kolterman, D.A., Munoz, M. A. and Mutt, J.M. 2006. Variation for anthracnose 
(Colletotrichum sublineolum) resistance within the sorghum germplasm collection from the Keys region of Mali, West Africa.

Rosado, A. W. C., Machado, A. R., Freire, F. C. O. and Pereira, O. L. 2016. Phylogeny, Identification, and pathogenicity of Lasiodiplodia associated with postharvest stem-end rot of coconut in Brazil, Plant Dis., 100:561-568.

Slippers, B. and Wingfield, M. J. 2007. Botryosphaeriaceae as endophytes and latent pathogens of woody plants: Diversity, ecology and impact. Fungal Biol. Rev., 21: 90 -106.

Slippers, B., Roux, J., Wingfield, M.J., Van der Walt, F.J.J., Jami, F., Mehl, J.W.M. and Marais, G.J. 2014. Confronting the constraints of morphological taxonomy in the Botryosphaeriales. Persoonia, 33: $155-168$.

Taylor, J. and Hyde, K.D. 2003. Micro fungi of tropical and temperate palms. Fungal Diver. Res. Series., 12: 1-459.

Viana, F.M.P., Uchoa Freire, C.N., Vieira, F. C. O., Mendes, F.N.P. and Saraiva, H.A.O. 2007. Tratamento do coco verde para exportacao com enfase no controle da podridao-basal-pos-colheita. In: Boletim de pesquisa e desenvolvimento 29, Embrapa Agroindustria Tropical, Fortaleza, Ceara, Brazil.

Waller J.M. and Lenne, J.M. (2002). Detection and isolation of fungal and bacterial pathogens. Plant Pathologist's pocketbook (3): www.mofa.gov.gh

\section{How to cite this article:}

Dheepa, R., C. Goplakrishnan, A. Kamalakannan, S. Nakkeeran, C.A. Mahalingam and Suresh, J. 2018. Coconut Nut Rot Disease in India: Prevalence, Characterization of Pathogen and Standardization of Inoculation Techniques. Int.J.Curr.Microbiol.App.Sci. 7(02): 2046-2057. doi: https://doi.org/10.20546/ijcmas.2018.702.245 